\title{
UPAYA PELESTARIAN POTENSI PARIWISATA DAN PENGEMBANGAN EKOWISATA KAWASAN KONSERVASI TAMAN WISATA ALAM BANGKO-BANGKO DESA BATUPUTIH KECAMATAN SEKOTONG KABUPATEN LOMBOK BARAT
}

\author{
${ }^{1}$ Nurin Rochayati, ${ }^{2}$ Agung Pramunarti, ${ }^{3}$ Agus Herianto \\ ${ }^{1,2,3}$ Dosen Program Studi Pendidikan Geografi, Universitas Muhammadiyah Mataram \\ Email: nurin.geo99@yahoo.com
}

\begin{abstract}
ABSTRAK
Tujuan penelitian ini adalah: 1) Untuk menjelaskan upaya BKSDA NTB dalam pelestarian potensi pariwisata yang terdapat di kawasan konservasi TWA Bangko-Bangko; 2) Untuk menjelaskan permasalahan yang dihadapi BKSDA NTB dalam pelestarian potensi pariwisata di kawasa konservasi TWA Bangko-Bangko; 3) Untuk menjelaskan penerapan konsep dan desain pengembangan ekowisata di kawasan konservasi TWA Bangko-Bangko. Dalam penelitian ini peneliti menggunakan metode penelitian kualitatif. Penelitian kualitatif adalah suatu proses penelitian ilmiah untuk memahami masalah-masalah manusia dalam konteks sosial dengan menciptakan gambaran menyeluruh dan kompleks yang disajikan, melaporkan pandangan terperinci dari para sumber informasi, serta dilakukan dalam setting yang alamiah tanpa adanya intervensi apa pun dari peneliti. Asumsi dari desain penelitian kualitatif lebih menekankan pada proses, bukannya hasil atau produk, peneliti merupakan instrumen kunci atau pokok, peneliti kualitatif melibatkan kerja lapangan, yaitu secara fisik berhubungan dengan orang, latar, lokasi atau institusi untuk mengamati atau mencatat perilaku dalam latar alamiah, dan proses penelitian kualitatif bersifat induktif. Dalam penelitian ini, peneliti memilih jenis pendekatan studi kasus. Adapun fokus pendekatan studi kasus adalah spesifikasi kasus dalam suatu kejadian baik itu yang mencakup individu, kelompok budaya ataupun suatu potret kehidupan.
\end{abstract}

Kata Kunci: Pelestarian Potensi Pariwisata dan Pengembangan Ekowisata

\section{PENDAHULUAN}

Potensi pariwisata yang cukup potensial dan banyak diminati oleh para wisatawan baik domestik maupun mancanegara di Propinsi Nusa Tenggara Barat (NTB) adalah pariwisata bahari (laut/pantai) karena secara geografis NTB yang terdiri dari 137 pulau (27 buah pulau yang berpenghuni dan 110 buah pulau yang tidak berpenghuni) merupakan propinsi kepulauan sekitar tujuh perdelapan wilayah NTB terdiri atas lautan dan potensi yang ada cukup menarik untuk dikembangkan menjadi kawasan pariwisata yang bermutu, yang nantinya mampu memberikan manfaat baik agi para wisatawan, masyarakat maupun pemerintah (Santosa, 2002).

Sementara itu, untuk Pulau Lombok sektor pariwisata merupakan salah satu sektor pembangunan yang memiliki potensi besar dalam pembangunan ekonomi. Keunggulan sektor pariwisata dijadikan motor penggerak perekonomian yang dapat dilihat dengan ditempatkannya sektor ini sebagai prioritas dalam pembiayaan pembangunan.

Pembangunan sektor pariwisata secara teoretis dan empiris tidak dapat dilepaskan dari daya dukung alam dan sosial budaya sebagai objek dan daya tarik wisatawan yang merupkan lingkungan dimana kegiatan kepariwisataan dilangsungkan. Sektor pariwisata tidak dapat dipisahkan dari isu lingkungan baik biofisik, kimia, sosial ekonomi dan budaya masyarakat sehingga pembangunannya tetap memperhatikan kaidah-kaidah pelestarian lingkungan hidup.

Secara konseptual ekotourisme atau ekowisata merupakan konsep pembangunan pariwisata berkelanjutan yang bertujuan mendukung upaya-upaya pelestarian lingkungan baik alam maupun budaya serta meningkatkan partisipasi masyarakat dalam pengelolaannya sehingga memberikan manfaat ekonomi kepada masyarakat dan pemerintah setempat (Achmad, 2002).

Berdasarkan hasil studi direktorat jenderal pariwisata dan Uinited Nation Divelopment Program (UNDP), maka pemerintah daerah NTB telah menetapkan Peraturan Daerah (PERDA) Nomor 9 tahun 1989 yang menetapkan 15 kawasan pengembangan pariwisata di NTB. Sementara itu, berdasarkan data yang diperoleh dari BKSD NTB terdapat 11 kawasan konservasi 
Taman Wisata Alam (TWA) dan salah satu diantaranya adala TWA Bangko-Bangko yang terletak di Desa Batu Putih Kecamatan Sekotong Kabupaten Lombok Barat.

Seperti wilayah NTB pada umumnya TWA Bangko-Bangko yang terletak di bagian selatan Pulau Lombok merupakan wilayah yang sangat kurang intensitas curah hujannya sehingga mengakibatkan terbatasnya lahan pertanian, tetapi di sisi lain dengan kurangnya intensitas curah hujan membuat TWA Bangko-Bangko memiliki air laut yang jernih terumbu karang yang unik dan sehat, ombaknya yang indah, pantai yang bersih dan pasir putih yang alami membuat objek wisata ini perlu untuk dijaga kelestariannya agar tetap alami, aman dan nyaman untuk dikunjungi oleh para wisatawan baik domistik maupun mancanegara serta dapat memberikan manfaat ekonomi bagi pemerintah dan masyarakat setempat.

Selain menawarkan potensi pariwista bahari, TWA Bangko-Bangko juga menawarkan potensi pariwisata berupa keindahan tofografi kawasan yang sangat bervariasi, hamparan hutan mangrove dan hutan jati yang masih terjaga kelestariannya memberikan daya tarik tersendiri bagi keindahan kawasan TWA Bangko-Bangko. Selain menawarkan potensi pariwisata alam tersebut di atas TWA BangkoBangko juga menawarkan atraksi wisata sejarah berupa dua buah meriam perang peninggalan Jepang pada masa perang duania ke-ll yang berada di ujung sebelah barat kawasan konservasi TWA Bangko-Bangko.

Berpariasinya atraksi wisata yang ditawarkan TWA Bangko-Bangko menjadi daya tarik tersendiri bagai wisatawan baik domestik maupun mancanegara, tetapi pada sisi lain TWA Bangko-Bangko memiliki persoalan yang cukup serius yaitu dijadikannya kawasan konservasi TWA Bangko-Bangko sebagai tempat permukiman oleh penduduk setempat, selain itu kawasan tersebut juga dijadikan sebagai daerah Transmigrasi Angakatan Darat (TRANSAD). Sementara itu, dalam peraturan perundangundangan yang berlaku kawasan konservasi harus bebas dari segala aktivitas penduduk dengan tujuan agar kelestarian kawasan konservasi tetap terjaga dan kegiatan wisata dapat dilakukan tetapi dengan mengusung konsep ekowisata.

Pentingnya masalah tersebut di atas, maka sebagai objek wisata konservasi perlu dilakukan penelitian mendalam tentang potensi pariwisata dan sejauh mana pengembangan ekowista dilakukan oleh Balai Konservasi Sumberdaya
Alam (BKSDA) NTB di kawasan tersebut dan inilah yang melatarbelakangi peneliti melakukan penelitian di kawasan konservasi TWA BangkoBangko dengan judul "Upaya Pelestarian Potensi Pariwisata dan Pengembangan Ekowisata Kawasan Konservasi Taman Wisata Alam Bangko-Bangko Desa Batu Putih Kecamatan Sekotong Kabupaten Lombok Barat".

\section{TINJAUAN PUSTAKA}

A. Pengertian Pariwisata

Istilah pariwisata menurut Poewodarmi dalam Ensiklopedia Nasioanal Indonesia Jilid 12 pariwisata berarti kegiatan perjalanan seseorang atau serombongan orang dari tempat tinggal asalnya ke suatu tempat di kota lain atau di negara lain dalam jangka waktu tertentu (Karyono, 1997). Sedangkan menurut (Suwantoro, 1997) menjelaskan bahwa pariwisata adalah kebutuhan manusia diseluruh dunia, sehinggga dengan meningkatnya kesejahteraan dan kemakmuran suatu bangsa dalam bidang ekonomi, maka muncul sifat manusia untuk melakukan perjalanan untuk sementara meninggalkan rutinitas di tempat tinggal mereka untuk mencari keseimbangan, keserasian dan kebahagiaan hidupnya. Proses kepergian ini akan terjadinya interaksi, saling berhubungan, perasaan-perasaan, persepsipersepsi, motivasi, tekanan-tekanan, kepuasan, kenikmatan dan lainya diantara sesama pribadi atau kelompok.

\section{B. Pengembangan Pariwisata}

Pada dasarnya pengembangan pariwisata adalah suatu proses yang berkesinambungan untuk melakukan matching dan adjustment yang terus menerus antara sisi supply dan demand kepariwisataan yang tersedia untuk mencapai misi yang telah ditentukan (Nuryanti, 1994). Sedangkan pengembangan potensi pariwisata mengandung makna upaya untuk lebih meningkatkan sumber daya yang dimiliki oleh suatu obyek wisata dengan cara melakukan pembangunan unsur-unsur fisik maupun non fisik dari sistem pariwisata sehingga meningkatkan produktivitas. Dalam hal ini yang dimaksud produktivitas obyek wisata berupa meningkatnya pendapatan daerah yang 
diperoleh dari kunjungan wisatawan yang masuk.

Disamping itu, untuk dapat melakukan pengembangan perlu memperhatikan berbagai aspek, suatu obyek wisata yang akan dikembangkan harus memperhatikan syaratsyarat pengembangan daerah menjadi obyek wisata yang dapat diandalkan, yaitu: 1) seleksi terhadap potensi, hal ini dilakukan untuk memilih dan menentukan potensi obyek wisata yang memungkinkan untuk dikembangkan sesuai dengan dana yang ada; 2) evaluasi letak potensi terhadap wilayah, pekerjaan ini mempunyai latar belakang pemikiran tentang ada atau tidaknya pertentangan atau kesalahpahaman antar wilayah administrasi yang terkait; 3) pengukuran jarak antar potensi, pekerjaan ini untuk mendapatkan informasi tentang jarak antar potensi, sehingga perlu adanya peta agihan potensi obyekwisata.

\section{Pengertian Ekowisata}

Ekowisata didefiniskan sebagai wisata asli yang bertanggung jawab, menghormati dan melestarikan lingkungan dan meningkatkan kesejahteraan penduduk lokal. Batasan lain menyebutkan bahwa ekowisata adalah suatu jenis pariwisata yang berwawasan lingkungan dengan aktivitas melihat, mempelajari, mengagumi alam, flora dan fauna, sosial bidaya etnis setempat, dan wisatawan yang melakukannya ikut membina kelestarian lingkungan alam sekitarnya dengan melibatkan penduduk lokal (Sudirman, 2002). Sedangkan menurut Sekarjakrarini menjelaskan bahwa ekowisata adalah konsep pengembangan dan penyelenggaraan pariwisata berbasis lingkungan alam dan budaya masyarakat setempat menuju pembangunan wisata berkelanjutan.

Dari definisi tersebut di atas, sangat jelas bahwa ekowisata dengan lingkungan memiliki hubungan yang sangat dekat dan saling berkaitan satu sama lain. Oleh karena itu pula aktivitas-aktivitas dalam ekowisata yang dikembangkan di TWA Bangko-Bangko haruslah tidak bersebrangan dengan prinsip-prinsip pelestarian lingkungan dan sosial budaya sekitarnya. Tetapi sebaliknya, dengan adanya ekowisata, maka upaya-upya pelestarian lingkungan dan budaya lokal di TWA BangkoBangko menjadi lebih bermakna serta memberikan dampak positif.
Dengan demikian ekowisata harus mengandung berbagai komponen antar lain: 1) memberikan kontribusi terhadap pelestarian sumberdaya keanekargam hayati; 2) meningkatkan kesejahteran masyarakat lokal; 3) mengandung muatan interfretasi, pembelajaran dan pengalaman; 4) adanya perilaku yang bertanggung jawab dari wisatawan dan industri pariwisata (Sudirman, 2002).

\section{Prinsip Ekowisata}

Adapun prinsip-prinsip ekowisata menurut (Crabetree.et.al, 2001) ada depalan prinsip penyelenggaraan ekowisata diantaranya yaitu: 1) memiliki fokus "natural area" yang memungkin wisatawan memiliki peluang menikmati alam secara personal dan secara langsung; 2) menyediakan interpretasi atau jasa pendidikan yang memberikan peluang pada wisatawan untuk menikmati alam sehingga mereka menjadi lebih mengerti, lebih mampu berapresiasi serta lebih menikmati; 3) kegiatan yang terbaik yang dapat dilakukan dalam rangka keberlanjutan secara ekologis; 4) memberikan kontribusi terhadap konservasi alam dan warisan budaya; 5) memberikan kontribusi secara kontinyu terhadap masyarakat lokal; 6) respek serta peka terhadap nili-nilai budaya yang ada di wilayah tersebut; 7) secara konsisten memenuhi harapan konsumen; 8) dipasrkan serta dipromosikan dengan jujur serta akurat sehingga kenyataan sesuai dengan harapan.

\section{E. Ekowista dan Pembanguan Pariwisata Berkelanjutan}

Ekowisata sebagai pilihan strategi pembangunan pariwisata berkelanjutan merupakn derivasi dari konsep pembangunan berkelanjutan (sustainable development). Munculnya konsep ini sebagai pilihan strategi pembangunan yang didorong oleh kenyataan bahwa: pertama, secara fisik model pembangunan yang dilakukan sebelumnya berkecendrungan mengancam daya dukung (carring capasity) lingkungan hidup yang terjadi adalah perusakan SDA secara permanen.

Kedua, secara konseptual model pembangunan yang ada telah menciptakan kesenjangan akses pada sumber-sumber ekonomi dan politik. Bila keadaan ini terus berlangsung, maka potensi ketegangan sosial akan mengancam keberlanjutan pembangunan itu sendiri. Untuk itu yang perlu ditekankan disini adalah bagaimana kedua hal tersebut di atas supaya dihindari dan hanya fokus pada model 
pembangunan pariwisata berkelanjutan dan ekowisata itu sendiri.

Pembangunan berkelanjutan merupakan suatu jenis pembangunan yang disatu pihak mengacu pada pemanfaatan sumber-sumber alam maupun SDM secara oftimal, dan dilain pihak serta pada saat yang sama memelihara keseimbangan optimal diantara berbagai tuntunan yang saling bertentangan terhadap sumber daya tersebut (Sudirman, 2002).

\section{METODE PENELITIAN}

Dalam penelitian ini peneliti menggunakan metode penelitian kualitatif. Sesuai dengan masalah dan fokus penelitian, maka subyek (informan) dalam penelitian ini adalah pihakpihak yang terlibat dalam pengelolaan kawasan konservasi taman wisata alam Bangko-Bangko dan pihak-pihak lain yang berkepentingan antara lain: 1) kepala dinas BKSDA NTB; 2) kepala dinas pariwisata NTB; 3) pemangku kepentingan dalam dunia pariwisata; 4) masyarakat sekitar kawasan konsrvasi dan: 4) wisatawan baik asing maupun domestik. Karena penelitian ini mempunyai implikasi luas dalam upaya pelestarian potensi pariwisata dan pengembangan ekowisata kawasan, dalam hal ini subyek penelitian dianggap mengetahui dan mengalami proses perkembangan kawasan tempat mereka terlibat di samping berpartisipasi mendukung perkembangan kawasan.

Adapun sumber data utama (sumber data primer) dalam penelitian ini ialah kata-kata dan tindakan selebihnya adalah data tambahan seperti dokumen dan data lainnya sebagai sumber data sekunder. Kata-kata dan tindakan orang-orang yang diamati atau diwawancarai merupakan sumber data utama. Sumber data utama dicatat melalui catatan tertulis atau melalui perekaman, pengambilan foto dan film.

Pengumpulan data di lapangan dengan menggunakan pengamatan partisipatif (observasi), wawancara mendalam dan dokumentasi. Dalam observasi, fokus pengamatan dilakukan terhadap tiga komponen utama, yaitu ruang/tempat, aktor atau pelaku dan aktivitas (kegiatan). Secara rinci data yang akan dikumpulkan dengan teknik ini adalah data tentang upaya pelestarian potensi pariwisata dan pengembangan ekowisata kawasan konservasi taman wisata alam Bangko-Bangko. Analisis data dalam penelitian kualitatif, dilakukan pada saat pengumpulan data berlangsung dan setelah selesai pengumpulan data. Analisis terdiri dari tiga alur kegiatan yaitu: reduksi data, penyajian data, penarikan kesimpulan/verifikasi.

\section{Hasil Penelitian}

A. Upaya BKSDA NTB dalam Pelestarian Potensi Wisata di Kawasan Konservasi TWA Bangko-Bangko

Keberadaan kawasan konservasi TWA Bangko-Bangko sesungguhnya akan dapat memberikan solusi terhadap pelestarian sumberdaya hutan baik flora maupun fauna yang keberadaannya mulai mengalami kepunahan akan tetapi jika peneliti melihat keadaannya saat ini keberaada TWA BangkoBangko tidak mencerminkannya sebagai kawasan konservasi. Fenomena yang sangat memprihatinkan dan tidak bersesuaian dengan Standar Operasional Prosedur (SOP) yang ada adalah terjadinya aktivitas pembakaran hutan atau lahan oleh masyarakat yang bertempat tinggal di dalam kawasan. Dan jika permasalahan ini dibiarkan terjadi terus menerus lalu bagaimana dengan keberadaan flora dan fauna langka yang keberadaannya di lindungi oleh pemerintah.

Berdasarkan hasil wawancara yang peneliti lakukan dengan salah seorang anggota masyarakat yang bertemapt tinggal di sekitar kawasan terkait dengan keberadaan kawasan konservasi TWA Bangko-Bangko ia menjelaskan bahwa:

"Sesungguhnya masyarakat Desa Batu Putih kurang setuju dengan keberadaan TWA Bangko Bangko adapun yang menjadi alasan sehingga masyarakat kurang setuju dengan keberadan kawasan ini adalah keadaan hutan itu sendiri, apa si yang ada di dalam hutan itu, hutan itu sama saja keadaannya dengan hutan yang lain tidak ada apakapaknya, lalu apa yang akan dijaga oleh pemerintah, apakah tidak sebaiknya hutan itu dikelola saja oleh masyarakat (Agus, wawancara tanggal 12 September 2015)".

Jika peneliti mencoba memahami apa yang dikatakan oleh masyarakat tersebut di atas dapat dijelaskan bahwa pemerintah dalam hal ini BKSDA NTB sepertinya belum memberikan 
pemahaman yang komprehensif terkait dengan pentingnya keberadaan kawasan konservasi TWA Bangko-Bangko bagi keberadaan flora dan fauna.

Melihat permasalahan yang begitu kompleks BKSDA NTB tentunya tidak tinggal diam dalam melestarikan potensi wisata di kawasan konservasi TWA Bangko-Bangko adapun upaya yang dilakukan BKSDA NTB dalam melakukan kegiatan pengelolaan antara lain adalah sebagai berikut: 1) penataan batas kawasan; 2) rencana pengelolaan jangka panjang; 3) evaluasi fungsi kawasan; 4) pemeliharaan jalur batas; dan 5) patrol rutin (Sumber: Buku Informasi Kawasan Konservasi NTB 2013).

Adapun sarana dan prasarana pengelolaan yang tersedia di kawasan konservasi TWA Bangko-Bangko antara lain adalah sebagai berikut: a) pondok kerja permanen; b) satu unit sepeda motor untuk kegiatan patroli rutin; c) shelter/berugak; d) satu unit computer; dan 5) satu unit radio komunikasi (Sumber: Buku Informasi Kawasan Konservasi NTB 2013).

Rencana pengelolaan yang didukung oleh keberadaan sarana dan prasarana serta keberadaan aparat keamanan (polisi hutan) sesungguhnya sudah memenuhi SOP yang dibutuhkan dalam pengeloaan TWA dan yang terpenting adalah implemetasi dari program pengeloaan yang sudah direncanakan harus dilaksanakan dengan sebaik-baiknya serta sikap tegas dari pemerintah mutlak dilakukan demi kelestarian kawasan.

\section{B. Permasalahan yang dihadapi BKSDA NTB dalam Pelestarian Potensi Wisata di Kawasan Konservasi TWA Bangko- Bangko}

Dalam Undang-undang No. 5 tahun 1990 tentang konservasi sumberdaya alam hayati dan ekosistemnya pada pasal 29 ayat satu dijelaskan bahwa "setiap orang dilarang melakukan kegiatan yang dapat mengakibatkan perubahan terhadap keutuhan suaka alam". Jika diperhatikan lebih cermat bunyi pasal satu di atas tegas bahwa di dalam kawasan konservasi tidak boleh ada aktivitas manuisa yang berhubungan dengan perubahan bentuk kawasan, tetapi pasal 29 ayat satu tersebut sangat kontras dengan situasi yang terjadi di kawasan konservasi TWA Bangko Bangko dari observasi yang peneliti lakukan di dalam kawasan konservasi terjadi aktivitas perambahan hutan dan penebangan liar yang sudah berlangsung cukup lama dan sangat susah untuk dicarikan jalan keluarnya. Hal ini bersesuaian dengan apa yang diungkapkan oleh polisi hutan I Wayan Pramayatna Agung (36 tahun) yang bertugas di kawasan konservasi TWA Bangko-Bangko bahwa:

"Kendala yang kita hadapi dalam melaksanakan tugas kami adalah banyaknya perambah yang ada di dalam kawasan konservasi, mereka menganggap kawasan ini sudah menjadi hak milik mereka sehingga susah untuk di atur dan kami sebagai petugas keamanan jika mau melakukan patroli kedalam kawasan biasanya kita tidak menggunakan baju dinas, hal ini kita lakukan untuk menghindari hal-hal yang tidak kami inginkan, karena masyarakat disini menganggap bahwa jika ada petugas yang menggunakan baju dinas mereka berpikir mereka akan di usir dari kawasan ini. Lalu permasalahan yang lain adalah masih adanya beberapa masyarakat yang melakukan penebangan kayu, tetapi selama saya bertugas disini belum pernah terjadi penebangan kayu (wawancara tanggal 24 Mei 2015)".

Dari hasil wawancara di atas maka dapat dijelaskan bahwa permasalahan yang di alami oleh kawasan konservasi TWA Bangko-Bangko adalah terjadinya perambahan hutan yang sudah berlangsung cukup lama dan masih berlangsung sampai pada hari ini dan permaslahan yang kedua adalah masih adanya penebangan liar di kawasan hutan dan jenis kayu yang mereka tebang adalah termasuk ke dalam jenis kayu yang dilindungi di kawasan konservasi yaitu kayu jati. Jika permasalahan klasik ini terjadi terus menerus maka dapat dikatakan bahwa rencana pengembangan pariwisata di kawasan konservasi ini tidak akan pernah bisa untuk dilakukan dengan maksimal padahal memiliki potensi wisata yang sangat bagus.

Untuk diketahui bahwa masyarakat yang tinggal di dalam kawasan konservasi TWA Bangko-Bangko dapat di klasifikasikan menjadi dua: Pertama, masyarakat perambah hutan yang bertempat tinggal di kawasan Kablet, Pemalikan Agung, dan Pemalikan Alit, mereka berasal dari berbagai kecamatan di Kabupaten Lombok Tengah dan Kabupaten Lombok Barat. Lalu yang kedua adalah masyarakat yang menempati tanah milik Transad (Transmigrasi 
Angakatan Darat) yang berada di wilayah Slegon. Berdasarkan hasil wawancara dengan Bapak Ikin (35 tahun) masyarakat perambah yang aslinya berasala dari Kecamatan Lembar dia mengatakan bahwa :

"Saya tinggal di sini kurang lebih sudah lima belas tahun buk, dari tahun 2000 saya sudah tinggal di sini, dulunya pertama kali kesini saya ikut sama orang tua buk dan aktivitas saya seharihari di kawasan ini adalah bertani dan berladang dan kadang-kadang mencari kerang dan kepiting di pinggir pantai (wawancara tanggal 26 Mei 2015)".

Hal senada juga diungkapkan oleh Bapak Mulaang (40 tahun) penggarap tanah milik Transmigrasi Angkata Darat (Transad) dalam wawancara dengan peneliti dia menjelaskan bahwa:

"Saya tinggal disini kurang lebih sudah tiga puluh tahun buk, saya datang kesini ikut orang tua. Dan Aktivitas kami sehari-hari adalah bertani buk, menggarap tanah milik Transad seluas 2 hektar dengan sistem bagi hasil dengan pemilik lahan (wawancara tanggal 28 Juni 2015).

Dari hasil wawancara di atas sekiranya dapat dijelaskan bahwa masyarakat yang tinggal di kawasan konservasi TWA Bangko Bangko dapat dikatakan bahwa mereka sudah tinggal cukup lama dan secara turun temurun padahal tegas dijelaskan bahwa barang siapa yang dengan sengaja tinggal dan merubah bentuk kawasan konservasi maka akan dikenakan sanksi hukum sebagaiman diatur dalam pasal 40 ayat 1.

Pada dasarnya masyarakat yang tinggal di kawasan konservasi baik masyarakat perambah maupun masyarakat penggarap tanah Transad sudah mengetahui bahwa tanah yang mereka tempati adalah termasuk ke dalam kawasan konservasi tetapi di sisi lain mereka beranggapan bahwa tanah tersebut adalah tanah yang diwariskan dari orang tua mereka. Berdasarkan petikan wawancara peneliti dengan Bapak Ikin (35 tahun) dia menjelaskan bahwa:

"Saya tahu dan kami tahu bahwa wilayah yang saya tempati ini adalah kawasan konservasi, tapi kan saya sudah lama tinggal di sini dan kami di sini beranggapan bahwa tanah yang kami tempati ini adalah tanah gege buk (wawancara tanggal 26 Mei 2015)".
Apa yang diungkapkan oleh pak Ikin sedikit berdeda dengan apa yang di tuturkan oleh Bapak Mulaang, dari hasil wawancara dia menerangkan bahwa :

"Yang saya tahu kawasan ini adalah milik Transad buk. Dan status kepemilikan saya terkait dengan tanah yang saya tempati dan saya garap adalah sebatas hak pakai saja buk, dan tanah pekarangan yang saya tempati ini adalah tanah Transad juga seluas 4 are buk (wawancara tangggal $28 \mathrm{Mei}$ 2015)."

Dari hasil wawancara di atas sekiranya dapat dijelaskan bahwa adanya pandangan yang berdeda antara perambah dengan pengelola tanh Tranasd. Perambah sudah menganggap bahwa tanah yang dia garap dan dia jadikan sebagai tempat tinggal adalah tanah gege atau tanah tidak bertuan yang oleh siapapun saja dapat memilikinya padahal sudah jelas tanah tersebut adalah bagian dari kawasan konservasi TWA Bangko-Bangko. Di sisi lain penggarap tanah Transad beranggapan bahwa tanah tersebut bukan merupakan tanah miliknya tapi hak guna pakai saja.

Kaitanya dengan tanah Transad petugas

Polisi Kehutanan Pak Agung (36 tahun) menjelaskan kepada penelti bahwa:

"Sebetulnya belum ada batasan yang jelas antara wilayah konservasi TWA Bnagko Bangko dengan tanah milik Transad, kita belum melakukan pengukuran secara langsung dilapanagan karena adanya beberapa kendala teknis (wawancara tanggal 24 Mei 2015)".

Sebetulnya jika pemerintah dalam hal ini Balai Konservasi Sumber Daya Alam Provinsi Nusa Tenggara Barat bertindak tegas terhadap situasi yang terjadi maka dalam jangka waktu yang tidak terlalu lama kawasan konservasi TWA Bangko Bangko akan dapat dikembangkan sesuai dengan rencana kerja yang sudah ditentukan sebelumnya, tetapi jika pemerintah tidak bertindak tegas maka TWA Bangko Bangko tidak akan mengalami perbaikan dan potensi yang ada di dalamnya tidak dapat dimanfaatkan dengan baik. Berdasarkan hasil wawancara peneliti dengan pihak perambah Pak Ikin (35 tahun) dia mengakatakan bahwa :

"Kami tidak pernah disuruh pergi buk, cuman dulu kami yang membuat 
penginapan di pinggir pantai ini pernah ada rencana mau digusur, tetapi kami di sini punya prinsip bahwa kalaui kami di gusur atau diusir jangan kami saja, tetapi semua masyarakat yang ada di dalam kawasan ini harus di usir supaya adil buk (wawancara tanggal $26 \mathrm{Mei}$ 2015)."

Dari pernyataan informan tersebut di atas dapat dijelaskan bahwa sebetulnya mereka mau saja untuk meninggalkan kawasan, tetapi selama ini tindakan tegas dari pemerintah belum dilakukan sepenuhnya. Menurut hemat peneliti mungkin perlu untuk dilakukan pendekatanpendekatan yang lebih baik artinya melibatkan semua unsur baik pemerintah selaku pemegang kebijakan, tokoh adat, tokoh agama, tokoh masyarakat, tokoh pemuda dan lain-lain. Dan jika mengacu pada pasal 19, pasal 21 dan pasal 24 tentng konservasi sumber daya alam dan ekosistemnya maka sudah jelas pemerintah berhak untuk melakukan tindakan tegas. Dan diluar pasal yang sudah di sebutkan di atas adapun hal-hal yang perlu diperhatikan bila mana mengunjungi kawasan konservasi TWA Bangko Bangko maka harus memperhatikan aturan-aturan di bawah ini antara lain:

1. Mempunyai simaksi (surat izin masuk wilayah konservasi) yang dapat diperoleh di Balai Konservasi Sumber Daya Alam NTB.

2. Dilarang membawa radio/tape/alat music yang akan mengganggu ketenangan satwa.

3. Dilarang membuat coretan, membuang sampah dan kegiatan lain yang bersifat merusak.

4. Ketika meninggalkan kawasan dilarang membawa tumbuhan hidup/mati dan atau bagian-bagiannya dan satwa hidup/mati dan atau bagian-bagiannya yang berasal dari kawasan tersebut.

5. Mintalah pendamping/pemandu dari balai konservasi sumber daya alam (BKSDANTB) setempat (Sumber: Buku Informasi Kawasan Konservasi NTB, 2013).

Aturan tersebut di atas sangat berbeda dengan apa yang peneliti lihat di lapanagan, padahal di pintu gerbang masuk wilayah konservasi TWA Bangko Bangko jelas dipungut biaya bagi siapapun yang akan berkunjung baik wisatawan asing maupun wisatawan mancanegara tetapi peneliti tidak melihat ada larangan dan pemeriksaan atau pembelian tiket masuk kepada siapapun yang berkunjung ke TWA Bangko Bangko. Kenyataan di atas diperjelas oleh seorang wisatawan lokal asal Kota Mataram Hafis (23 thaun) mangatakan:

"Tadinya si saya berpikir akan dipungut biaya atau karcis masuk bu, karena akan memasuki wilayah konservasi, tetapi ternyata tidak, dan dipintu masuk saya melihat orang-orang pada keluar masuk tanpa anda pemeriksaan khusus dari petugas (wawancara tanggal 28 Mei 2015).

Mungkin saja petugas membiarkan hal ini terjadi karena didasari oleh pertimbanganpertimbangan tertentu karena mereka memahami tentang situasi dan kondisi yang saat ini terjadi di kawasan konservasi TWA Bangko Bangko. Tetapi jika masalah ini dibiarkan terus berlanjut maka TWA Bangko Bangko yang sesungguhnya menyimpan potensi wisata yang sangat bagus tidak dapat memberikan manfaat yang besar terhadap masyarakat.

\section{Penerapan Konsep dan Desain Pengembangan Ekowisata di Kawasan Konservasi TWA Bangko-Bangko}

Seiring dengan isu "back to nature" yang semakin popular akhir-akhir ini, kegiatan wisata yang memanfaatkan alam sebagai atraksi utamanya semakin marak. Penghargaan wisatawan terhdap sesuatu yang alami umumnya lebih tinggi nilainya dibandingkan dengan yang bersifat artificial.

Apalagi jika kondisi alam, flora dan fauna yang dijadikan atraksi wisata tersebut bersifat unik maka wisatawan siap mengeluarkan uang puluhan sampai ratusan dolar untuk mengunjungi daerah tersebut. Melihat kecendrungan ini maka wisata alam sepertinya merupakan kegiatan yang potensial untuk dikembangkan termasuk di kawasan konservasi TWA Bangko Bangko. Apalagi semakin banyak orang stress akibat kehidupan yang semakin sibuk serta tuntutan kerja yang semakin intens, maka kerinduan untuk beristirahat sejenak, menghilangkan kepenatan hidup muncul kepermukaan. Salah satu yang semakin sering dilakoni oleh mereka adalah kembali melihat daerah yang masih asli, alami, yang maish indah dan penuh kedamaian.

Dalam konteks pengelolaan konservasi TWA Bangko Bangko, ekowisata bermakna menyelenggarakan kegiatan wisata yang secara 
ekonomi dapat berkelanjutan dan memberikan manfaat langsung kepada masyarakat setempat serta mendukung upaya pelestarian lingkungan (alam dan budaya).

Pengembangan pariwisata di TWA tentunya harus mengacu kepada ketentuan dan aturan yang berlaku sebagai taman wisata alam dan harus memperhatikan pelestarian ekosistem lingkungan yang ada sehingga pada saat pembangunan fasilitas wisata seperti hotel dan fasilitas lainnya disesuaikan dengan kondisi yang ada. Adapun hal-hal yang cukup menarik dan mempunyai nlai estetika yang cukup tinggi di bangun di sela- sela pepohonan dengan arsitektur bagunan yang menyatu dengan lingkungan. $\mathrm{Di}$ sisi lain tidak terdapat pagar batas antara hotel dengan hutan sehingga berbagai jenis satwa dapat masuk di areal hotel, hal ini merupakan obyek dan daya tarik tersendiri yang sangat menyenangkan bagi wisatawan, di tambah dengan kondisi lingkungan pantai yang indah dan dapt melihat berbagai jensi ikan pantai yang cukup jinak dan hamparan hutan yang cukup sejuk.

Dari hasil pengamatan peneliti di lapangan bahwa kawasan konsrvasi TWA Bangko Bangko mempunyai nilai jual yang sangat tinggi dan pada umumnya dikunjungi oleh wisatawan baik nusantara maupun mancanegara. Pembangunan sarana dan prasarana wisata harus secepatnya dilakukan karena dari yang peneliti amati dilapangan belum ada satupun sarana wista yang sudah dibangun oleh pihak pemerintah baik hotel maupun fasilitas lainnya. Hanya ada beberapa penginapan atau home stay illegal yang berjejer di pinggir pantai yang dibuat oleh masyarakat perambah yang ada di dalam kawasan konservais TWA Bangko Bangko.

\section{PEMBAHASAN}

Keberadaan TWA Bangko Bangko sebagai kawasan konservasi terluas di NTB harus mendapat dukungan penuh dari masyarakat khususnya masyarakat sekitar kawasan agar program kerja yang sudah dan akan dilakukan oleh pemerintah dalam rangka melestarikan potensi sumberdaya yang ada di dalam kawasan berjalan dengan baik. Namun yang terjadi malah sebaliknya, berdasarkan hasil observasi dan wawancara yang peneliti lakukan malah masyarakat sekitar sesungguhnya kurang setuju dengan keberadaan kawasan konservasi TWA Bangko Bangko.
Peliknya permasalahan di kawasan konservasi TWA Bangko Bangko perlu segera dicarikan jalan keluar. Sampai saat ini di dalam kawasan konservasi TWA Bangko Bangko terdapat delapan permukiman liar yaitu: 1) Selegong; 2) Pemalikan Alit; 3) Pemalikan Agung; 4) Kablet; 5) Pandanan; 6) Bangko Bangko; 7) Teluk Waru; dan 8) Pondok Pace. Dari ke delapan permukiman liar ini hanya Selegong dan Bangko Bangko yang tercacat secara adminstratif masuk di kawasan Desa Batu Putih.

Masyarakat mengklaim bahwa tanah yang mereka tempati secara turun temurun selama berpuluh-puluh tahun ini adalah tanah Gege atau tanah yang tidak bertuan. Bangunan rumah yang mereka bangun adalah bangunan permanen. Adapun aktivitas masyarakat yang tinggal di dalam kawasan konservasi TWA Bangko Bangko adalah sebagai perambah hutan dan akibat dari aktivitas perambahan ini adalah terjadinya kerusakan hutan yang tidak terhindarkan lagi yang selanjutnya mengakibatkan punahnya sebahagiaan flora dan fauna yang di lindungi di kawasan ini.

Selain melakukan perambahan hutan secara mebabi buta tanpa mempertimbangkan dampak yang ditimbulkan, masyarakat juga membuat home stay untuk para wisatawan mancanegara yang datang ke TWA Bangko Bangko untuk menikmati aktivitas wisata seperti surfing, sun bathing, swimming dan fishing. Home stay yang mereka buat adalah illegal alias tidak berizin.

Permasalahan terkait dengan perambahan hutan di dalam kawasan konservasi TWA Bangko Bangko harus segera dicarikan solusinya. Pemerintah sebagai pemegang kebijakan harus bekerja keras dalam menangani permasalahan yang ada selama ini. Program pengelolaan yang sudah direncanakan harus segera diimplementasikan. Pengukuran tapal batas yang belum jelas dan relokasi masyarakat di dalam kawasan harus dilakukan dengan secepatnya karena dua hal inilah sesungguhnya yang menjadi penyakit dalam pelestarian potensi pariwisata di kawasan konservasi TWA Bangko Bangko.

Tumpang tindih kepentingan yang terjadi selama ini antara pemerintah dan masyarakat disebabkan oleh tidak adanya sinkronisasi berbagai unsur dalam hal ini adalah pemerintah, Dewan Perwakilan Rakyat Daerah (DPRD), tokoh masyarakat, tokoh agama, tokoh adat serta akademisi. Sinkronisasi ini dibutuhkan agar tercermin pembangunan pariwisata yang 
berkelanjutan dan berwawasan lingkungan dengan berbasis kepada masyarakat.

Jika permasalahan terkait dengan tumpang tindih kepentingan yang ada selama ini sudah dapat di atasi dengan baik tanpa adanya pihak yang merasa dikorbankan atau dirugikan maka konsep pengembangan ekowisata di kawasan ini akan dengan sangat mudah untuk dilaksanakan. Ekowisata sendiri adalah penyelenggaraan kegiatan wisata yang bertanggung jawab di tempat-tempat alami atau daerah-daerah yang dikelola berdasarkan keadaan alam, yang mendukung upaya-upaya pelestarian lingkungan (alam dan budaya) dan meningkatkan kesejahteraan masyarakat setempat (Anonim, 1996).

Pada prinsipnya pengembangan ekowisata di kawasan konservasi TWA Bangko Bangko sesungguhnya belum diterapkan dengan maksimal hal ini disebabkan oleh tumpang tidik kepentingan atau sengketa lahan antara pihak pemerintah dengan masyarakat khususnya masyarakat yang berada di dalam kawasan. Tetapi pada parakteknya konsep ekowisata sesungguhnya sudah mulai di galakkan oleh para wisatawan khususnya wisatawan asing. Hal ini bisa peneliti amati dari kegiatan para wisatawan yang sedang berwisata di TWA Bangko Bangko. Mereka mengumpulkan anak-anak kecil usia SD yang tinggal di pinggir pantai selanjutnya mereka diberikan plastik dengan ukuran cukup besar dan mereka di suruh untuk lomba memungut sampah anorganik yang bertebaran di sepanjang pantai dan barang siapa di antara anak-anak tersebut yang mendapatkan sampah paling banyak maka akan diberikan hadiah baik berupa barang maupun uang.

Kegiatan membersihakan pantai khusunya di lokasi surfing sudah dilakukan berkali-kali oleh para wisatawan hal ini menunjukkan bahwa konsep ekowisata di kawasan tersebut sudah berlangsung cukup lama. Artinya wisatawan sesungguhnya sangat bertanggung jawab terhadap kelestarian lingkungan dengan memanfaatkan anak-anak yang tinggal di kawasan tersebut untuk membersihkan pantai dan sebagai imbalan mereka (wisatawan) memberikan upah kepada mereka. Artinya, selain kebersihan pantai yang tetap terjaga dampak secara ekonimis juga dirasakan oleh masyarakat sekitar. Hal ini sudah mencerminkan tentang konsep ekowisata. Menghormati dan melestarikan lingkungan dan meningkatkan kesejahteraan penduduk lokal.
Oleh karena itu, dalam menyongsong kecendrungan kepekaan wisatawan terhadap isu-isu lingkungan yang semakin tinggi di masa mendatang, maka pemahaman akan konsep ekowisata serta penerapan standarnya menjadi semakin penting. Hal ini juga perlu didukung dengan menyelengarakan sertifikasi produk ekowisata serta pemasaran produk-produk tersebut sehingga industri pariwisata lebih tertarik mengikuti program sertifikasi yang menyebabkan daya saing lebih kuat di pasaran.

\section{KESIMPULAN DAN SARAN \\ A. Kesimpulan}

Adapun upaya BKSDA NTB dalam pelestarian potensi wisata di kawasan konservasi TWA Bangko Bangko antara lain adalah: 1) penataan batas kawasan; 2) rencana pengelolaan jangka panjang; 3) evaluasi fungsi kawasan; 4) pemeliharaan jalur batas; dan 5) patrol rutin (sumber, buku informasi kawasan konservasi NTB 2013). Sementara itu, permasalahan yang dihadapi BKSDA NTB dalam pelestarian potensi wisata di kawasan konservasi TWA Bangko Bangko sangat kompleks mulai dari penetapan tapal batas kawasan yang belum tuntas, perambahan hutan, adanya perumahan di dalam kawasan, adanya lembaga pendidikan formal dan non formal serta tersdianya penginapan ilegal (home stay) bagi wisatawan yang dibangun oleh masyarakat yang berada di dalam kawasan.

Sementara itu, penerapan konsep dan desain pengembangan ekowisata di kawasan konservasi TWA Bangko Bangko tentunya harus mengacu kepada ketentuan dan aturan yang berlaku sebagai taman wisata alam dan harus memperhatikan pelestarian ekosistem lingkungan yang ada sehingga pada saat pembangunan fasilitas wisata seperti hotel dan fasilitas lainnya disesuaikan dengan kondisi yang ada. Adapun hal-hal yang cukup menarik dan mempunyai nlai estetika yang cukup tinggi dibangun di sela-sela pepohonan dengan arsitektur bagunan yang menyatu dengan lingkungan. Di sisi lain tidak terdapat pagar batas antara hotel dengan hutan sehingga berbagai jenis satwa dapat masuk di areal hotel, hal ini merupakan obyek dan daya tarik tersendiri yang sangat menyenangkan bagi wisatawan, di tambah dengan kondisi lingkungan pantai yang indah dan dapt melihat berbagai jenis ikan pantai dan hamparan hutan yang cukup sejuk. 


\section{B. Saran-saran}

Dalam upaya mendukung program pengelolaan kawasan yang sudah direncanakan maka pihak BKSDA NTB penting untuk melakukan beberapa hal di bawah ini:

1. Diperlukan rencana pengelolaan yang berwawasan lingkungan dengan memperhatikan eksistensi kawasan konservasi.

2. Dibangunnya sarana dan prasarana wisata baik berupa hotel maupun fasilitas pendukung lainnya.

3. Masyarakat perambah yang bermukim di dalam kawasan konservasi TWA Bangko Bangko harus ditindak dengan tegas sesuai dengan peraturan perundang-undangan yang berlaku dan jika hal ini tidak segera dilakukan maka mustahil pemerintah mampu melakukan pengelolaan dengan maksimal.

4. Batasan antara kawasan konservasi dengan tanah milik Transad perlu untuk dibenahi dengan segera agar proses pemgembangan kawasan dapat dilakukan dengan maksimal.

5. Dalam pelaksanaan ekowisata hendaknya diikuti aturan pengelolaan yang jelas sesuai dengan prinsip dan konsep ekowisata.

6. Semua aturan yang dibuat dalam rangka pengelolaan ekowisata yang terencana dan professional harus disusun secara kolaboratif antara pemerintah, masyarakat sekitar kawasan dan LSM yang membidangi masalah lingkungan hidup.

7. Tumpang tindih kepentingan antara masyarakat dan pemerintah terkait dengan kawasan konservasi harus segera diselesaikan.

\section{DAFTAR PUSTAKA}

Achmad, Mahfud. 2002. Potensi dan Pengembangan Ekoturisme di Nusa Tenggara Barat. Mataram: Dinas Kebudayaan dan Pariwisata Nusa Tenggara Barat.

Crabtree et al. 2002. Setting a Wordwide Standard For Ecotourism: Sharing Experience in Ecotourism Certification:
Develoving and Ecotourism Standartd. A Paper Presented on the World Ecotourism Summit, Quebec. 12 pp. EAA, NEAP, CRC for Sustainable Tourism of Australia and Green Globe 21.

Hamid, Abdul. 1987. Geografi Pariwisata Indonesia. Jakarta: Yayasan Bakti Membangun.

Karyono, Hari.1997. Kepariwisataan. Jakarta: PT Gramedia Indonesia.

Miles and Hubermanl.1994. Qualitatif Data Analysis (Second Edition). London: Sage Publications Inc.

Pendit, Nyoman S. 1994. Perencanaan Pembangunan Regional dan Kawasan untuk Kepariwisataan Alam. Jakarta: Yayasan Bakti Membangun.

Peraturan Daerah Nusa Tenggra Barat (PERDA-NTB) Nomor 9 tahun 1989 tentang kepariwisatan.

Prastowo, Andi. 2011. Metode Penelitian Kualitatif dalam Perspektif Rancangan Penelitian. Jakarta: Ar-Ruzza Media.

Propil Taman Wista Alam Bangko-bangko Nusa Tenggara Barat. Mataram: Balai Konservasi Taman Wista Alam NTB.

Santoso, Didik, 2002. Potensi dan Pengembangan Ekotourisme di Nusa Tenggara Barat. Mataram: Dinas Kebudayaan dan Pariwisata Nusa Tenggra Barat.

Spillane, James S. 1987. Pariwisata Indonesia Sejarah dan Prospeknya. Yogyakarta: Andi.

Spillane, James S. 1994. Pariwisata Indonesia Siasat Ekonomi dan Rekayasa Kebudayaan. Yogyakarta: Kanisius.

Sudirman. 2002. Ekotourisme dan Pembangunan Berkelanjutan yang Berwawasan Lingkungan. Mataram. Dinas Kebudayaan dan Pariwisata Nusa Tenggra Barat.

Sujali, 1989. Geografi Pariwisata dan Kepariwisataan. Yogyakarta: Fakultas Geografi Universitas Gadjah Mada.

Suwantoro, Gamal. 1997. Dasar-dasar Pariwisata. Yogyakarta: Penerbit Andi

Undang-undang No. 9 Tahun 1990 Tentang Kepariwisataan.

Yoeti, Oka A. 1997. Perencanaan dan Pengembangan Pariwisata. Jakarta: Pradnya Paramita. 